laid before the Trustees at their next meeting, and be ready for issue very shortly afterwards. Thus, after a period of twenty-five years, this most important piece of ornithological work has been brought to a conclusion. No human product is perfect, and the Catalogue has been, and will be, the subject of many criticisms. One obvious defect in it is its want of uniformity, the various authors having been permitted, owing to the wise discretion of the authorities, very liberal opportunities for the expression of their own views in their respective portions, although a general adherence to one plan has been rightly insisted upon. But when the enormous amount of labour required for this work, and the absolute necessity of employing more than one author upon such a huge task are considered, it will be obvious that greater uniformity was practically unattainable. In the case of the "Catalogue of Reptiles and Batrachians," where the series of specimens and species was not so large, the herpetologists are fortunate in having had the whole of the work performed upon a uniform system by the indefatigable energy of a single naturalist.

The "Catalogue of Birds," as complete in twenty-seven volumes, gives us an account of 11,614 species of this class of Vertebrates, divided into 2255 genera and 124 families. It has been prepared by eleven authors, all members of the British Ornithologists' Union, and with one exception, I believe (who is not a resident in England), now or formerly members of this Club. I think it will be universally allowed that we have, in this case, a great and most useful undertaking brought to a successful conclusion.

Another good piece of ornithological work, likewise the product of a member of this Club, which has just made its appearance, is Mr. Beddard's volume on the "Structure and Classification of Birds." It seems to me to be a most useful manual on this subject, profusely illustrated, and full of convenient references to further information on various points which it would have been impossible to compress into a single volume. It will be found to be a mine of wealth to those who choose to dig in it, and contains a good summary, not only of the results arrived at by Mr. Beddard himself, but also by Garrod and Forbes, his illustrious predecessors in the office which he holds.

Mr. A. H. Evans, whose volume upon Birds for the "Cambridge Natural History" we have been long expecting, informs me that this work is finished, except the index, and will be shortly published. We shall all weicome its appearance with the greatest pleasure. A second work that Mr. Evans, together with Mr. Scott Wilson, is engaged upon is the "Aves Hawaiienses," of which we have long been waiting for the final part. This, I am assured, is now in a forward state, and is likely to be issued without further delay.

From information received from $\mathrm{Mr}$. Rothschild, I am pleased to be able to say that his somewhat parallel illustrated work on the "Avifauna of Laysan," of which the last part was issued in 1893 , will also be shortly brought to a conclusion, and that the third and final part will be issued in the course of next year. Taken together, these two works will form a most valuable contribution to our knowledge of the Avifauna of the Northern Pacific. I must also not forget to mention, amongst recent contributions to our science, the excellent work of Dr. Meyer and Mr. Wiglesworth on the birds of Celebes-one of the most elaborate and complete ornithological monographs on the birds of a special district ever prepared. Celebes, I may remark, as a debatable land between the Australian and Oriental regions, was in special need of the full treatment and discussion which it has here received from the authors of this work.

But the brethren of the B. O. C. and their friends, I think I may say, are at prosent not less active in the field than in the cabinet. We are fortunate in having with us to-night the two principal members of the new expedition to Socotra and Southern Arabia, which will leave England on the 28th inst. It will, of course, take up natural history in every branch, but with Dr. Forbes and Mr. Ogilvie Grant as its leaders, and a trained taxidermist in attendance, we need not fear that the interests of Ornithology will in any way be overlooked. In Socotra itself much has been already done, but little or nothing bas been ascertained ornithologically of the southern coast of Arabia, and we know, from Bent's writings, that even in this commonly supposed barren district, bird-life is abundant in certain spots, which we trust may be within reach of the Expedition.

$$
\text { NO. I } 520 \text {, VOL. 59] }
$$

Besides the Socotran Expedition many other explorations by various members of the $\mathrm{B}$. O. U. are in progress or in contemplation. Captain Boyd Alexander, who has worked so well in the Cape Verde Islands, is struggling through the middle of Africa from the Cape to Cairo. Under present circumstances he seems likely to come out successfully, and will, no doubt, bring information on birds, if not specimens, with him. Mr. Lort Phillips hopes to return to his favourite quarters in Somaliland during the course of the present winter, and expects to get together the supplementary materials still required for the preparation of his proposed work on the birds of that most interesting country. Mr. John Whitehead, who has added so much to our knowledge of the zoology of the Philippines, proposes to return to the same country very shortly, in order to continue his researches in a field which he knows so well and in which he takes such great interest. Before leaving, he has placed in the hands of the editors of The Ibis a series of valuable field-notes on the birds collected during his last journey. These will appear in the forthcoming volume of our journal. Mr. Alfred Sharpe, C. B., who is shortly returning to his post in Nyasaland, promises to continue the employment of collectors in different parts of that Protectorate, the zoology of which he, following in the footsteps of Sir Harry Johnston, has already done so much to investigate.

Finally, I may remark that, as will be seen on turning over the pages of contents in the last volume of The Ibis, we have correspondents interested in our favourite subject in nearly every part of the world, and that the great difficulty of the editors is to compress so many valuable contributions within the compass of an annual volume.

Before resuming my seat, I wish to say one more word. Our Government, in connection with that of Egypt, has just taken possession of an enormous district in Africa, probably nearly equal to half Europe in extent. It sternly warns all intruders off, even when they are alleged to be of "no political influence." When it comes to regulate the administration of these new territories, it is to be hoped that the interests of natural history will not be entirely overlooked. Although the Upper Nile districts have been traversed and investigated by many well-known naturalists, there is still very much to be done in these teeming regions of animal-life. We Englishmen are ready and willing to undertake, by individual efforts, much work that in other countries is provided for by State explorers; but it is not too much to expect that our Government should at least help us by providing adequate facilities and occasional assistance, and even, perhaps, by contributions to the expensive process of bringing the results thus acquired completely before the world.

\section{THE ECONOMIC EFFECTS OF SHIP CANALS}

I $\mathrm{N}$ a paper submitted to the American Academy of Political and Social Science by Mr. J. A. Fairlie, on "The Economic Effects of Ship Canals," it is pointed out that while the construction of the North Sea Canal doubled the tonnage of the shipping of Amsterdam in the first six years after it was opened, the effect was purely local, as will be that also of the Manchester Ship Canal; and that although the Welland, Corinth and Kiel Canals have larger possibilities, their actual consequences have as yet been small. With the Suez and Sault Saint Marie Canals the results have been both important and far-reaching, and have affected the trade of the world. Both these canals have led to a rapid change in the material and character of the vessels used; to important changes in the sources of production; to the development of the growth of wheat in the countries which they serve ; and to a large reduction in the cost of bread and other food in this country.

The Suez Canal opened in 1870 with a traffic of 486 vessels having a tonnage of 436,000 tons ; in $189 \mathrm{r}$, the record year, the traffic had increased to $8,700,000$ tons. The new route by effecting a saving of 3000 miles on the voyage from the ports of Western Europe to the East, or almost half the distance to Bombay, brought about a complete revolution in the character of the shipping business to the East. By the Cape route coaling places were few, and the facilities for coaling expensive ; the consequence was that owing to this, and the large space occupied by coal, to the exclusion of paying cargo, sailing vessels were more profitable than steamers. By the canal, steamers can coal at Gibraltar, Malta, Port Said and Aden; consequently, 
owing to these facilities and the shorter distance, sailing vessels soon became superseded by steamers, and it was estimated that $2,000,000$ tons of vessels were thus thrown out of employment. Under the old system, when voyages from India took the greater part of a year, and the time of arrival could not be calculated within a month or two, it was necessary to keep large stocks to meet the varying demand for goods, and hence the erection of the enormous range of warehouses at the India Docks. Steamers by way of the canal make the voyage in thirty days, and the time of their arrival can be regulated within a day or two shorter voyages and punctuality of arrival make it possible for merchants to order direct from the East, and hence less capital is required and the cost of warehousing saved. The Suez Canal has had a material effect in fostering the growth and export to this country of Indian tea, which has increased from I I to 120 million pounds. The export of rice from India has also enormously increased since the opening of the canal, and now constitutes the largest single item in the export trade of India. When the only route was round by the Cape the difficulty in transporting wheat, owing to its liability to heat during the voyage, and the loss from weevils, made the export of grain unprofitable. Since the opening of the canal India has become the second exporting country of the world, the exports of grain amounting now to over $50,000,000$ bushels.

Other merchandise, both of import and export, has been affected to a less degree; the shorter route has also rendered possible the export from Australia and New Zealand of very large quantities of meat, fruit and other food products.

The Saint Mary Falls Canal, commonly called "The Soo," has now a traffic even larger than that of the Suez Canal, and exceeds the total foreign trade of the port of New York. The development of the trade now carried on over the Great Lakes is almost entirely due to this "Soo" canal. The size of vessels engaged in the navigation in 1870 averaged 175 tons; now there are five lines, owning sixty steamships of from $175^{\circ}$ to 3000 tons. The increase in trade is due in a great measure to the opening out of the iron mines of northern Michigan and Wisconsin, which have been made available by the canal route from the mines to the ports in the southern lakes. But the most important factor in the increase of the navigation is the transport of wheat and flour, the low rates at which these can be carried by water encouraging the growth over a very widely extended area of country. The other resources which have been developed by the construction of this canal are timber, coal and copper. One conspicuous feature due to this canal is the immense increase in population in the Lake Superior region and the development of towns.

\section{ANTHROPOLOGY AT THE BRITISH} ASSOCIATION.

THE Anthropological Section met in the Park Place Schoolroom, under the presidency of Mr. E. W. Brabrook, C. B., ex-President of the Anthropological Institute.

On Thursday, September 8, the morning's programme consisted mainly of papers on physical anthropology.

The sixth annual Report of the Committee on the mental and physical deviations from the normal among children in public elementary and other schools was read by Mr. White Wallis, and gave a further account of those children whose mental and physical condition renders them unfitted for the public education provided in ordinary elementary day schools. The new information has been mostly obtained by studying the correlations of the cases, and the facts tabulated show that great difficulties must arise in making any provision for the proper care of these children, who show a much greater tendency than average children to become delicate under an adverse environment. The large proportion of both boys and girls who present "abnormal nerve-signs" shows the importance of trying to remove each such sign by carefully adapted physical training, and that the improvement of the brain condition of such children below the average in mental and physical development requires skilled teachers and good hygienic surroundings.

Mr. O. H. Howarth read a paper on human life at high altitudes, with the object of determining whether the adaptability of man to extreme conditions is of comparatively recent development, or of gradual growth. He exhibited an object which he regarded as a stone celt, found at an elevation of 7700 feet in the Rocky Mountains in Colorado. As causes of human inhabitation of extreme altitudes, he named the pursuit of industries impracticable elsewhere, and seclusion for religious purposes, and enumerated the conditions favourable and unfavourable to the persistence of human life under these conditions. $\mathrm{He}$ described numerous specialised superstitions ; especially the impulse to establish cults on high peaks, and the belief in disembodied spirits, leading to a variety of precautions to prevent their interference. In the discussion which followed, Dr. Beddoe pointed out that Tibet, which was the highest average altitude in the world, was the only place in which real theocracy existed, and that the shepherds in remote parts of Australia often became demented because they were so much alone. Dr. Francis Galton thought it would be worth while to observe the behaviour of animals in high altitudes. Prof. Tylor suggested that some attention might also be directed to the collection of literature dealing with this subject. Mr. C. H. Read regarded the object exhibited by Mr. Howarth as a purely natural production, not a manufactured implement. Dr. G. A. Dorsey and Dr. J. G. Garson continued the discussion. Mr. Howarth briefly replied.

Miss M. A. Ellis presented a note on the human ear as a means of identification, stating that ears do not change shape after childhood, and classifying the great varieties of shape by marking off the helix into five divisions. Various types of ears were exhibited, and a brief discussion followed.

Mr. K. Minakata's paper on Tabu in Japan was read in abstract.

Mr. G. Leith read an important paper on a large and varied collection of stone implements from South Africa, describing the situation and characteristics of the bushmen's haunts, in some of which were found implements and other signs of occupation, just as they had been left years ago ; and remarking upon the various types of stone implements which are found both in the cave deposit, and in the talus in front of the cave. With these poisoned arrows the bushmen were a dangerous enemy to the Boers, even when the latter were equipped with firearms. The investigation of Lighthouse Cave, at Cape St. Blaize, led to the discovery of many fine specimens of skinning knives, scrapers, and flaked implements, indicating that it had been a place for the manufacture of these implements for many ages. Alluding to his researches in various beds of gravel at various altitudes in which he discovered large numbers of palæolithic stone implements of very remarkable size and shape, he classified the latter, according to their position, into neolithic or modern, palæolithic or ancient, and eolithic. The evidence of these gravels proved without doubt, in his opinion, that South Africa was the home of man at a very remote period of history. The eoliths found there corresponded exactly with the plateau implements found on the Kentish Weald by Mr. Harrison. Prof. Dawkins did not think that the evidence was clear as to their belonging to the Gravel ages, and had no doubt that he could find a parallel from North America for the specimens produced.

Mr. F. T. Elworthy described a number of Roman symbolic hands from Pompeii and elsewhere, of the kind known as Mano Pantea; contending that these hands are not votive offerings, but in fact the Roman Penates. Mr. A. J. Evans and Mr. E. S. Hartland pointed out that these hands all belong to the late heterogeneous cults of the early empire, and have no connection with the indigenous family cults of Italy. Mr. J. L. Myres described other examples exhibited in the British Museum, one of which bears a definitely votive inscription. Bishop Brownlow commented on the Christian benedictory use of the gesture represented in these pre-Christian hands.

Mr. H. Warington Smyth described the river craft in use among the Siamese, explaining the construction of the "dugout "Me Kawng boats, and discussing the various native types. To this was appended a brief description of the simple fourteenreed instrument in use among the Lao of the Me Kawng Valley, illustrated by an example of this characteristic and monotonous music.

On Friday, September 9, after the President's address, Dr. Beddoe gave a summary account of the mediæral population of Bristol, based on two series of skulls, the one medirval, the other probably of the eighteenth century, disinterred on the occasion of the removal of St. Werburgh's church, and on certain lists of surnames of various dates. $\mathrm{He}$ found the mediæval skulls very generally small, short and broad (cephalic index $80^{\circ} 0$ ), while the later ones exhibited the same long types that characterise the present population of 